Case Report Paper

\title{
The Relationship between Post Natal Care and Premature Baby Health in RSKD Ibu \& Anak Siti Fatimah Makassar
}

\author{
Jamila Kasim ${ }^{1}$, Ratna ${ }^{1}$, Sri Suryani ${ }^{2}$, Oktovina Suka ${ }^{1}$ \\ ${ }^{1}$ Sekolah Tinggi Ilmu Kesehatan Nani Hasanuddin. Makassar, Indonesia. \\ ${ }^{2}$ Universitas Hasanuddin. Makassar, Indonesia.
}

\begin{abstract}
Article History
Received:

20.01.2020

Revised:

27.02.2020

Accepted:

03.03.2020

*Corresponding Author:

Ratna

Email:

ns.ratna@stikesnh.ac.id
\end{abstract}

This is an open access article, licensed under: $\mathrm{CC}-\mathrm{BY}-\mathrm{SA}$
Abstract: Premature babies are babies born alive before the 37th week of pregnancy calculated from the first day of the last menstrual period. Baby care in an incubator is a method of caring for infants by putting the baby in a device that serves to help create adequate ambient temperatures with normal temperatures. Providing optimal nutrition is important in the management of premature and very low weight babies. Prevention of infection is the most important part of every newborn component. The purpose of this study was to determine the relationship between post natal care and premature baby health at the Siti Fatimah Makassar Hospital. This study is a cross sectional study, the population in this study were all babies born at gestational age less than 37 weeks and who were temporarily undergoing treatment at Siti Fatimah Hospital Makassar. Sampling using purposive sampling, obtained 30 samples according to inclusion criteria. Data collection is done in a primary way with direct observation techniques. The collected data is then processed and analyzed using Microsoft Excel computer programs and statistical programs (SPSS) version 6.0. Data analysis includes univariate analysis by looking for frequency distribution, bivariate analysis with chi-square test $(x<0.05)$, to determine the relationship between variables. The results of the bivariate analysis found a relationship between postnatal care with premature infant health $(\mathrm{p}=0.033)$.

Keywords: Baby Health, Post Natal Care, Premature Baby. 